\title{
Role of Ovarian Hormones in the Long-term Control of Glucose Homeostasis
}

\section{Effects on Insulin Secretion}

\author{
C. J. Bailey and H. Ahmed-Sorour \\ Department of Biological Sciences, University of Aston in Birmingham, Birmingham, England
}

\begin{abstract}
Summary. The role of ovarian hormones in the longterm control of B-cell function in the mouse has been examined. Ovariectomised adult female mice were treated with daily subcutaneous replacement doses of oestradiol $(5 \mu \mathrm{g} / \mathrm{kg})$, progesterone $(1 \mathrm{mg} / \mathrm{kg})$, both hormones combined, or vehicle only for 15 weeks. Ovariectomy caused a $40 \%$ increase in plasma glucose concentrations during glucose tolerance tests, a $26 \%$ decrease in the plasma insulin response to glucose $(2 \mathrm{~g} / \mathrm{kg} \mathrm{IP})$ and a $32 \%$ decrease in the plasma insulin response to arginine ( $2 \mathrm{~g} / \mathrm{kg}$ IP) compared with control mice. When islets from ovariectomised mice were incubated for 30 minutes in media containing $28 \mathrm{mmol} / 1$ glucose or $2.8 \mathrm{mmol} / 1$ glucose with $5 \mathrm{mmol} / 1$ arginine, insulin release was reduced by $23 \%$ and $31 \%$ respectively. Total pancreatic and islet insulin content were each decreased by $36 \%$, and the number of B-cells was decreased by $39 \%$ in the ovariectomised mice. These detrimental effects of ovariectomy were partially or totally prevented by the oestradiol and progesterone treatments. The results indicate that ovarian oestrogens and progestogens may play an important role in the long-term maintenance of B-cell competence in the female mouse.
\end{abstract}

Key words: Ovariectomy, oestradiol, progesterone, glucose tolerance, insulin release, pancreatic islets, mouse.

It has been shown that ovariectomy increases the incidence and severity of experimental diabetes in female animals [1]. These effects are opposed by natural oestrogens, which produce islet hypertrophy and hyperplasia, and increased B-cell granulation
[1-4]. In non-diabetic female animals physiological amounts of oestrogens or progesterone administered for 2 to 3 weeks lower blood glucose concentrations and increase circulating insulin levels [5-7].

However, a possible physiological role of ovarian hormones in the long-term control of B-cell function in the female has not been investigated. We have therefore examined the effects of prolonged (15 weeks) ovarian endocrine deficiency and oestradiol-progesterone replacement regimens on B-cell function in ovariectomised female mice.

\section{Materials and Methods}

\begin{abstract}
Animals
Adult female albino mice (A. Tuck \& Sons Ltd., Battlesbridge) were housed in an air-conditioned room at $22 \pm 2{ }^{\circ} \mathrm{C}$ with a regular lighting schedule of $9.5 \mathrm{~h}$ light $(0800-1730 \mathrm{~h})$ and $14.5 \mathrm{~h}$ dark. The mice were supplied a standard pellet diet (Mouse breeding diet, Heygate \& Sons Ltd., Northampton) and tap water ad libitum except prior to and during certain experiments, as indicated.
\end{abstract}

\section{Chemicals}

Oestradiol- $17 \beta$ and progesterone were purchased from Sigma Chemical Co., Poole, England. Insulin antiserum (double antibody batch K5402) was purchased from Wellcome Reagents, Beckenham, England; ${ }^{25}$ I-insulin from the Radiochemical Centre, Amersham, England; mouse insulin (batch M20169) from Novo, Bagsvaerd, Denmark; and insulin-free bovine serum albumin (fraction V) from Armour Pharmaceutical Co., Eastbourne, England. Other chemicals were purchased from $\mathrm{BDH}$ Chemicals, Poole, England, and May and Baker, Dagenham, England.

\section{Experimental Design}

Mice were bilaterally ovariectomised under sodium pentobarbitone anaesthesia $(45 \mathrm{mg} / \mathrm{kg} \mathrm{IP})$ at 10 weeks of age and treatments were begun 1 week later. Groups of mice were treated for 


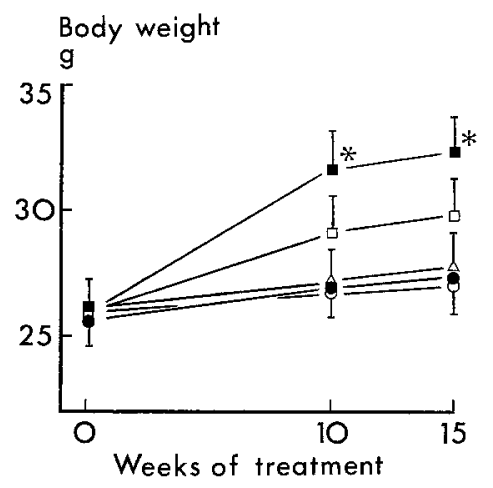

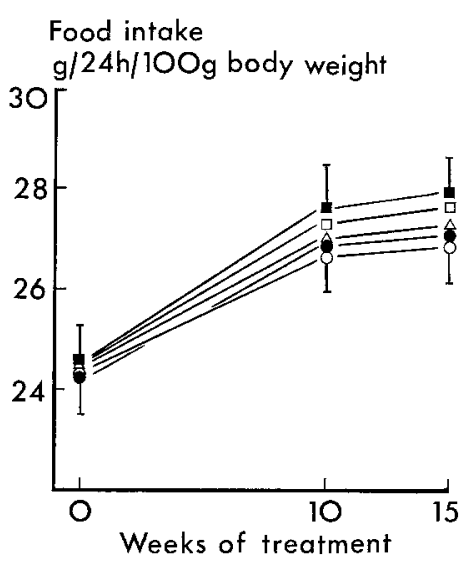

Fig. 1. Body weight and food intake in intact control $(\bullet)$, ovariectomised $(\mathbf{\square})$, oestradiol $(O)$, progesterone $(\square)$ and oestradiol-progesterone $(\triangle)$ treated mice. Values are mean \pm SEM of 12-15 mice. * $p<0.05$ compared with control, oestradiol and oestradiol-progesterone groups
15 weeks with daily SC injections at $0900 \mathrm{~h}$ of either oestradiol$17 \beta 5 \mu \mathrm{g} / \mathrm{kg}$, progesterone $1 \mathrm{mg} / \mathrm{kg}$, both hormones combined doses as previously, or vehicle only $(0.8 \mathrm{ml} / \mathrm{kg}$ arachis oil $)$. Intact control mice were sham-operated and treated with vehicle only. All tests were begun $24 \mathrm{~h}$ after the last hormone injection of week 15 of the treatment.

Since glucose homeostasis varies during the oestrous cycle, all tests on intact female mice were performed on the day of dioestrus, as determined by a vaginal smear [6]. Dioestrus corresponds to the lowest circulating levels of gonadal steroids [8].

\section{Food Intake}

Food intake was measured over 4 consecutive periods of $24 \mathrm{~h}$ during the week before ovariectomy, and during weeks 10 and 15 of treatment as described elsewhere [9].

\section{Glucose and Arginine Tests In Vivo}

Glucose tolerance tests were conducted on $12 \mathrm{~h}$ fasted mice and arginine tests on $24 \mathrm{~h}$ fasted mice. Food was withheld during the tests. Glucose $(2 \mathrm{~g} / \mathrm{kg})$ or arginine hydrochloride $(2 \mathrm{~g} / \mathrm{kg})$ was given IP. Blood samples $(100 \mu \mathrm{l})$ were obtained from the cut tip of the tail immediately before the test substance was injected, and at 30 and $60 \mathrm{~min}$ after glucose, and at 15 and $30 \mathrm{~min}$ after arginine. Plasma was separated and analysed for glucose and insulin.

\section{Incubation and Perifusion of Isolated Islets}

Mice were fasted for $24 \mathrm{~h}$ and killed by decapitation. The splenic portion of the pancreas was removed and islets of similar size were isolated by microdissection. Gey and Gey buffer [10], $\mathrm{pH} 7.4$ containing bovine serum albumin $(0.2 \mathrm{mg} / \mathrm{ml})$, glucose and arginine as described below, was used throughout.

For incubation experiments groups of 3 islets were transferred to vials containing $2 \mathrm{ml}$ of medium containing $2.8 \mathrm{mmol} / 1$ glucose. The medium was preoxygenated with a gas phase of $\mathrm{O}_{2}$ and $\mathrm{CO}_{2}$ $(95: 5)$. Preincubations were performed at $37^{\circ} \mathrm{C}$ for $30 \mathrm{~min}$ with constant gentle agitation and oxygenation. The medium was then removed and the islets were washed twice with fresh medium. Test incubations were performed for $30 \mathrm{~min}$ under the same conditions as the preincubations, with either low glucose $(2.8 \mathrm{mmol} / 1)$, high glucose $(28 \mathrm{mmol} / \mathrm{l})$ or low glucose and arginine $(5 \mathrm{mmol} / \mathrm{l})$. To allow for residual insulin from the preincubation, the test medium was sampled for insulin content at the beginning and end of the test incubation. The difference was expressed as insulin release in $\mathrm{ng} / \mathrm{ml} / 3$ islets $/ 30 \mathrm{~min}$.

For perifusion experiments groups of 10 microdissected islets were transferred to a Millipore Filtration Unit, $1 \mathrm{ml}$ capacity. The islets were preperifused at $500 \mu \mathrm{l} / \mathrm{min}$ for $30 \mathrm{~min}$ with oxygenated medium, $37^{\circ} \mathrm{C}$ containing $2.8 \mathrm{mmol} / \mathrm{l}$ glucose. Test perifusions were performed for $30 \mathrm{~min}$ with medium containing $28 \mathrm{mmol} / \mathrm{l}$ glucose, and effluent medium was assayed for insulin at $0,1,2,3$, $4,5,10,15$ and $30 \mathrm{~min}$. At the end of the perifusion, islets were dried at $105^{\circ} \mathrm{C}$ for $24 \mathrm{~h}$ and weighed. Insulin release was expressed in $\mathrm{ng} / \mathrm{ml} / \mu \mathrm{g}$. islet tissue.

\section{Insulin Content of Pancreas and Islets}

Mice were fasted for $24 \mathrm{~h}$ and killed by decapitation. Insulin was extracted from either total pancreas or groups of 10 microdissected islets by the acid-ethanol procedure of Malaisse et al. [11]. Insulin content was expressed as $\mu \mathrm{g} / \mathrm{g}$ or $\mu \mathrm{g} / \mathrm{mg}$ wet weight of pancreas or islet tissue respectively.

\section{Glucose and Insulin Assays}

Samples of plasma, incubation and perifusion media, and tissue extracts were stored at $-20^{\circ} \mathrm{C}$. Plasma glucose was determined by an automated glucose oxidase procedure (Beckman Glucose Analyzer, Beckman Riic Limited, High Wycombe) and insulin was determined by double antibody radioimmunoassay [12] using mouse insulin as standard. The sensitivity of the assay, as defined by Midgley et al. [13] was $0.18 \mathrm{ng} / \mathrm{ml}$ and the intra-assay coefficient of variation was $3.58 \%$.

\section{Islet Morphometry}

Pancrea were fixed in Bouin's solution, dehydrated in ethanol and embedded in paraffin wax. Sections of $6 \mu \mathrm{m}$ thickness were stained with aldehyde fuchsin [14] counterstained with $2 \%$ aqueous light green. Five sections from each of 6-9 pancrea per group were selected from the head through to the tail of the pancreas and assessed for islet number, islet size and B-cell number. Islets were counted using a squared graticule at $\times 250$ magnification. The number of islets was expressed per $\mathrm{cm}^{2}$ of pancreas section. To assess islet size the longest and shortest diameters were measured using a scaled graticule at $\times 250$ magnification, and the average diameter was calculated. B-cells were counted using a squared graticule at $\times 400$ magnification. The number of B-cells was expressed per $\mathrm{mm}^{2}$ of pancreas section. 


\section{Statistical Method}

Groups of data were compared using Student's t test. Differences were considered to be significant if $\mathrm{p}<0.05$.

\section{Results}

\section{Body Weight and Food Intake (Fig. 1)}

Body weight was elevated in ovariectomised mice compared with all other groups except those treated with progesterone alone. Treatment with progesterone alone did not lower body weight significantly. Food intake was similar in the five groups of mice at the time intervals studied (10 and 15 weeks).

\section{Fed and Fasting Plasma Glucose and Insulin} (Table 1)

Fasting plasma glucose concentrations were consistently higher in ovariectomised mice than in control mice. Treatment with the three hormone regimens lowered glucose concentrations compared with the ovariectomised group. In the fed state there were no significant differences between the five groups of mice.

Plasma insulin concentrations were not significantly altered in fed or fasting ovariectomised mice compared with control mice. Treatment with the three hormone regimens significantly raised insulin concentrations in the 6- and 12-hour fasted states compared with both control and ovariectomised mice.

\section{Glucose Tolerance (Table 2)}

Glucose tolerance was impaired in ovariectomised mice, whereas tolerance in the three groups of hormone treated mice was similar to controls. The plasma insulin response to glucose was diminished in the ovariectomised mice, while mice treated with oestradiol alone and the combined oestradiol-progesterone regimen showed a greater response than control mice.

\section{Arginine Administration In Vivo (Fig. 2)}

Arginine administration slightly raised and then lowered plasma glucose concentrations in all mice. Ovariectomy did not significantly increase glucose concentrations, although progesterone lowered glucose concentrations. The plasma insulin response to arginine was reduced in ovarectomised mice and restored in the three groups of hormone treated mice.

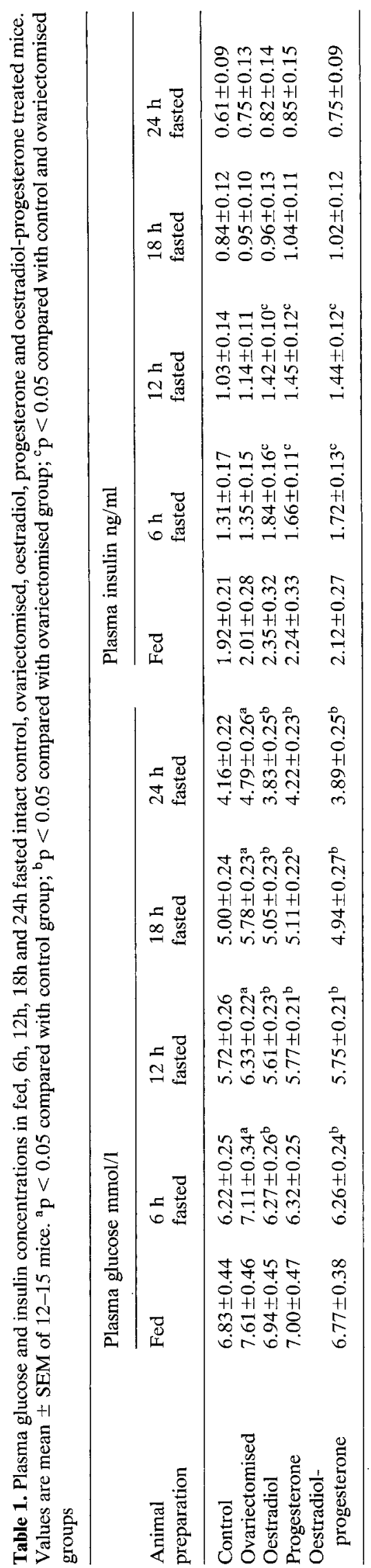


Table 2. Plasma glucose and insulin concentrations during intraperitoneal glucose tolerance tests in 12 hour fasted intact control, ovariectomised, oestradiol, progesterone and oestradiol-progesterone treated mice. Values are mean \pm SEM of $8-9$ mice. ${ }^{a} \mathrm{p}<0.02$, ${ }^{b} p<0.05$ compared with all other group; ${ }^{\mathrm{c}} \mathrm{p}<0.05$ compared with control and ovariectomised groups; ${ }^{\mathrm{d}} \mathrm{p}<0.05$ compared with ovariectomised group

\begin{tabular}{|c|c|c|c|c|c|c|}
\hline \multirow{2}{*}{$\begin{array}{l}\text { Animal } \\
\text { preparation }\end{array}$} & \multicolumn{3}{|c|}{ Plasma glucose $\mathrm{mmol} / 1$} & \multicolumn{3}{|c|}{ Plasma insulin $\mathrm{ng} / \mathrm{ml}$} \\
\hline & $0 \mathrm{~min}$ & $30 \mathrm{~min}$ & $60 \mathrm{~min}$ & $0 \mathrm{~min}$ & $30 \mathrm{~min}$ & $60 \mathrm{~min}$ \\
\hline Control & $5.68 \pm 0.27$ & $9.94 \pm 0.61$ & $6.38 \pm 0.45$ & $1.01 \pm 0.13$ & $3.27 \pm 0.21$ & $1.85 \pm 0.19$ \\
\hline Ovariectomised & $6.37 \pm 0.23^{b}$ & $12.76 \pm 0.72^{\mathrm{a}}$ & $8.61 \pm 0.56^{b}$ & $1.15 \pm 0.10$ & $2.53 \pm 0.26^{\mathrm{b}}$ & $1.64 \pm 0.19$ \\
\hline Oestradiol & $5.65 \pm 0.26$ & $9.27 \pm 0.50$ & $6.66 \pm 0.49$ & $1.44 \pm 0.12^{\mathrm{c}}$ & $3.93 \pm 0.15^{\mathrm{c}}$ & $2.18 \pm 0.13^{\mathrm{d}}$ \\
\hline Progesterone & $5.77 \pm 0.24$ & $9.45 \pm 0.55$ & $6.88 \pm 0.44$ & $1.48 \pm 0.13^{c}$ & $3.71 \pm 0.25$ & $1.98 \pm 0.24$ \\
\hline \multirow{2}{*}{$\begin{array}{l}\text { Oestradiol- } \\
\text { progesterone }\end{array}$} & & & & & & \\
\hline & $5.70 \pm 0.21$ & $8.94 \pm 0.62$ & $6.50 \pm 0.43$ & $1.47 \pm 0.13^{\mathrm{c}}$ & $4.01 \pm 0.22^{\mathrm{c}}$ & $2.43 \pm 0.18^{c}$ \\
\hline
\end{tabular}
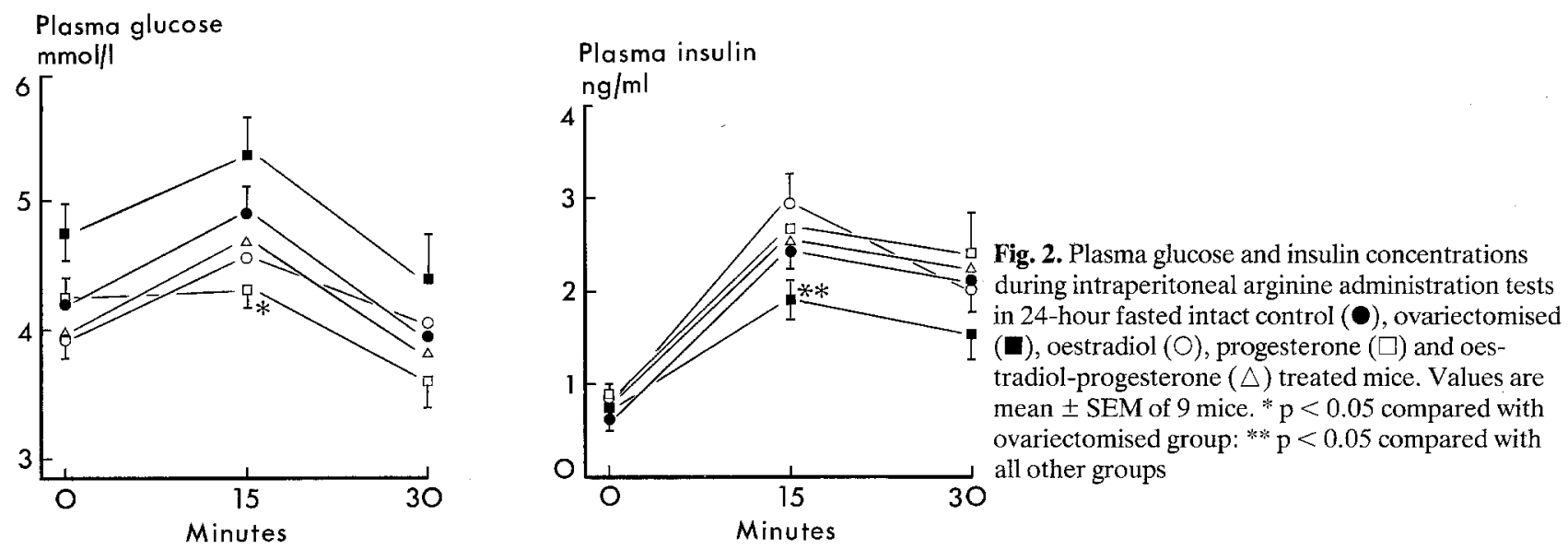

Table 3. Insulin release during incubation of islets isolated from 24 hour fasted intact control, ovariectomised, oestradiol, progesterone and oestradiol-progesterone treated mice. Values are mean \pm SEM of 9 determinations. ${ }^{a} \mathrm{p}<0.05$ compared with all other groups; ${ }^{b} \mathrm{p}<0.05$ compared with control and ovariectomised groups

\begin{tabular}{llcc}
\hline Animal preparation & \multicolumn{2}{l}{ Insulin release $\mathrm{ng} / \mathrm{ml} / 3$ islets/30 min } \\
\cline { 2 - 4 } & Glucose $2.8 \mathrm{mmol} / \mathrm{l}$ & Glucose $28 \mathrm{mmol} / \mathrm{l}$ & $\begin{array}{c}\text { Glucose } 2.8 \mathrm{mmol} / \mathrm{l} \text { and } \\
\text { arginine } 5 \mathrm{mmol} / 1\end{array}$ \\
\hline Control & $2.24 \pm 0.26$ & $7.73 \pm 0.49$ & $10.81 \pm 0.73$ \\
Ovariectomised & $2.01 \pm 0.47$ & $5.92 \pm 0.59^{\mathrm{a}}$ & $7.40 \pm 0.85^{\mathrm{a}}$ \\
Oestradiol & $2.42 \pm 0.39$ & $10.23 \pm 0.94^{\mathrm{b}}$ & $10.97 \pm 1.10$ \\
Progesterone & $2.52 \pm 0.41$ & $9.28 \pm 0.96$ & $11.20 \pm 0.93$ \\
Oestradiol- & $2.49 \pm 0.36$ & $10.70 \pm 0.86^{\mathrm{b}}$ & $11.41 \pm 1.14$ \\
\hline
\end{tabular}

\section{Insulin Release In Vitro}

Incubations (Table 3). Basal insulin release from islets incubated for 30 minutes in the presence of $2.8 \mathrm{mmol} / 1$ glucose was not significantly altered by ovariectomy, or by the three hormone treatments. Glucose-stimulated insulin release $(28 \mathrm{mmol} / 1 \mathrm{glu}-$ cose) was reduced by ovariectomy and restored by each of the hormone treatments. Similarly, the insu- lin response to arginine $(5 \mathrm{mmol} / \mathrm{l})$ in the presence of $2.8 \mathrm{mmol} / \mathrm{l}$ glucose was reduced by ovariectomy and restored by the hormone treatments.

Perifusion (Fig. 3). A square-wave increase in the glucose concentration of the perifusion medium from 2.8 to $28 \mathrm{mmol} / 1$ produced a biphasic release of insulin from islets of all five groups of mice. Both the first (1-5 $\mathrm{min}$ ) and the second ( $5 \mathrm{~min}$ onwards) phases of 


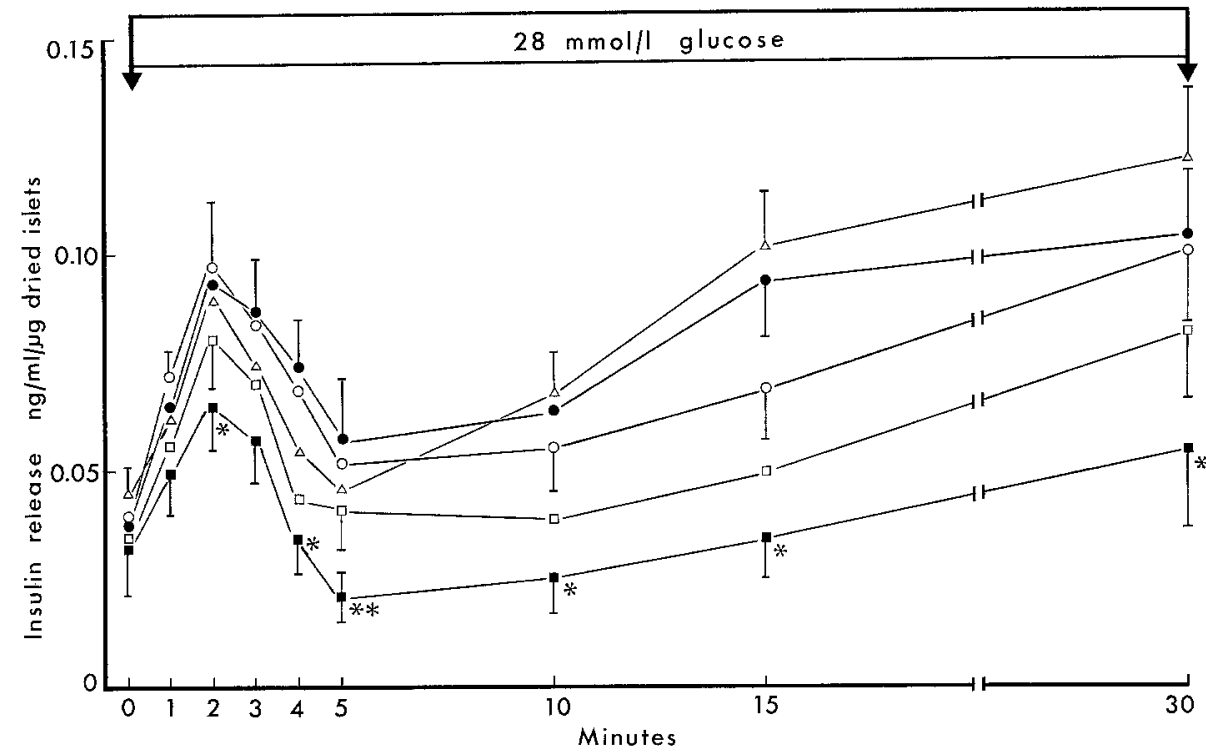

Fig. 3. Insulin release during perifusion of islets isolated from 24 hour fasted intact control (@), ovariectomised ( $)$, oestradiol (O), progesterone $(\square)$ and oestradiol-progesterone $(\triangle)$ treated mice. The mice were treated for 15 weeks. Details of the perifusion procedure are given in the Materials and Methods section of the text. Values are mean \pm SEM of 9 determinations. $* \mathrm{p}<0.05$ compared with control, oestradiol and oestradiol-progesterone groups; ** $p<0.05$ compared with all other groups

Table 4. Insulin content of total pancreas and isolated islets, islet number, islet size and B-cell number in intact control, ovariectomised, oestradiol, progesterone and oestradiol-progesterone treated mice. Insulin content of total pancreas and isolated islets was determined after a 24 hour fast: values are mean \pm SEM of 5-6 mice. Values for islet number, islet size and B-cell number are mean \pm SEM of 5 pancreas sections from each of $6-9$ mice. ${ }^{a} \mathrm{p}<0.02,{ }^{b} \mathrm{p}<0.05$ compared with all other groups, ${ }^{\mathrm{c}} \mathrm{p}<0.05$ compared with control and progesterone groups, ${ }^{\mathrm{d}} \mathrm{p}<0.05$ compared with ovariectomised group

\begin{tabular}{|c|c|c|c|c|c|}
\hline $\begin{array}{l}\text { Animal } \\
\text { preparation }\end{array}$ & $\begin{array}{l}\text { Total pancreatic } \\
\text { insulin content } \\
\mu \mathrm{g} / \mathrm{g} \text { wet wt }\end{array}$ & $\begin{array}{l}\text { Islet insulin } \\
\text { content } \\
\mu \mathrm{g} / \mathrm{mg} \text { wet wt }\end{array}$ & $\begin{array}{l}\text { Islet number } / \mathrm{cm}^{2} \\
\text { pancreas secretion }\end{array}$ & $\begin{array}{l}\text { Islet size } \\
\text { average diameter } \\
\mu\end{array}$ & $\begin{array}{l}\text { B-cell } \\
\text { number } / \mathrm{mm}^{2} \\
\text { pancreas section }\end{array}$ \\
\hline Control & $139 \pm 21$ & $21.7 \pm 1.2$ & $45 \pm 9$ & $103 \pm 11$ & $148 \pm 13$ \\
\hline Ovariectomised & $88 \pm 12^{b}$ & $13.8 \pm 1.8^{\mathrm{a}}$ & $36 \pm 5$ & $90 \pm 10$ & $89 \pm 11^{b}$ \\
\hline Oestradiol & $197 \pm 42$ & $25.2 \pm 1.3^{c}$ & $53 \pm 6^{d}$ & $104 \pm 10$ & $131 \pm 12$ \\
\hline Progesterone & $141 \pm 18$ & $20.1 \pm 1.1$ & $40 \pm 5$ & $95 \pm 9$ & $118 \pm 12$ \\
\hline $\begin{array}{l}\text { Oestradiol- } \\
\text { progesterone }\end{array}$ & $180 \pm 33$ & $22.6 \pm 1.6$ & $46 \pm 5$ & $101 \pm 9$ & $134 \pm 17$ \\
\hline
\end{tabular}

insulin release were diminished by ovariectomy and partially or totally restored by the three hormone regimens.

\section{Insulin Content of Pancreas and Islets (Table 4)}

Total pancreatic insulin and the insulin content of the islets were considerably reduced in ovariectomised mice. The hormone treatments increased the insulin content of both total pancreas and the islets. Treatment with oestradiol produced a greater effect than progesterone, and the combined oestradiol-progesterone treatment produced an intermediate effect.

\section{Islet Number and Size, and B-cell Number (Table 4)}

Islet number and size were not significantly different in ovariectomised and control mice. However, islet number was increased in oestradiol treated mice compared with ovariectomised mice. The number of B-cells was reduced by ovariectomy, while each hormone treatment opposed this effect.

\section{Discussion}

The results demonstrate that ovarian hormones play an important role in the long-term integrity of islet B-cells in the female mouse. In addition the data illustrate that replacement doses of ovarian hormones exert a beneficial long-term effect on glucose homeostasis, and influence the long-term control of body weight.

Studies in mice and other rodents have shown that ovariectomy temporarily increases food intake, whereas oestrogens (but not progesterone) cause a transient decrease in food intake [15-17]. Transient changes in food intake (during the first 2 to 3 weeks 
of treatment) were not examined in the present study. However, food intake was not significantly different between the five groups of mice after 10 and 15 weeks. This indicates that any transient effects on food intake are restored by 10 weeks.

Ovariectomy produced a persistent increase in body weight which was totally prevented by replacement with oestradiol, but not progesterone. This is consistent with the short-term weight limiting effect of oestrogens described by others $[15,16]$. Progesterone is reported to antagonise this effect of oestrogens, although progesterone does not appear to exert a significant effect on body weight (at physiological concentrations) in the absence of oestrogens $[15,17]$. The lack of a significant effect of progesterone alone was confirmed in the present study, but the dose used was not sufficient to significantly antagonise the effect of oestradiol. It has been suggested that the weight-limiting effect of oestrogens is mediated by the hypothalamus and involves a readjustment to the set point for weight regulation $[15,18]$. The present data indicate that this is achieved in the long-term without a measurable change in food intake.

Although transient fluctuations in food intake and small protracted adjustments of body weight are known to affect glucose homeostasis [19] the magnitude and duration of these changes were not sufficient to account for the marked alterations in glucose tolerance and B-cell integrity in the present study. Thus, the long-term effects of sex hormones on islet B-cells and gluco-regulation appear to be independent of food intake and body weight.

The deterioration of glucose tolerance and reduced plasma insulin response to glucose after long-term ovariectomy, and the improvements conferred by physiological replacement doses of oestradiol and progesterone are consistent with shortterm studies in other rodents [5-7]. Since glucoseinduced insulin release in vitro was also reduced by ovariectomy and restored by the hormone replacements, the changes in glucose tolerance may be attributed in part to changes in insulin secretion. However, it has been suggested that sex steroids influence insulin resistance. There are reports that oestrogens increase the sensitivity of adipose tissue and skeletal muscle to the actions of insulin [20], while progesterone marginally antagonises the hypoglycaemic action of insulin [21]. These effects remain to be clarified with long-term studies at physiological doses.

The effects of ovariectomy and sex hormone replacements on arginine-induced insulin release were similar to those on glucose-induced insulin release. It is notable that progesterone lowered the plasma glucose response to arginine, although other treatments did not produce a significant effect. This action of progesterone has been observed in other species and may reflect different effects of oestrogens and progesterone on the handling of amino acids by muscle and liver [22, 23].

Perifusion studies revealed that both the first and second phases of glucose-stimulated insulin release are reduced in the long-term absence of ovarian hormones, and partially or totally returned by replacement with physiological doses of oestradiol and progesterone. Larger doses administered for shorter periods do not consistently reproduce these effects $[24,25]$. Addition of oestradiol and progesterone to the islets in vitro has shown that an immediate and direct effect on insulin secretion does not occur ([5, 26, 27,] Lenzen, S., personal communication, 1979), but the effects of these steroids are evident 6 hours after administration in vivo [26]. Progesterone, but not oestradiol, has been shown to increase insulin release directly after 6 hours [26] and after 20 hours [27]. Progesterone has also been shown to enter the nuclei of islet cells [28] and increase islet cyclic AMP levels [29], although it does not appear to alter adenylate cyclase activity [27].

In addition to a direct effect on the islet $B$ cells, sex hormones may influence insulin secretion via their effects on other endocrine glands. Oestrogens have been shown to increase circulating concentrations of growth hormone and free cortisol [4, 30, 31] which would tend to increase plasma insulin concentrations [32]. Conversely there is evidence that progesterone depresses growth hormone secretion [22]. Since the protective action of oestrogens in experimentally diabetic rats occurs after hypophysectomy and adrenalectomy $[1,2]$ it appears that pituitary and adrenal hormones do not represent an important mode of action of oestrogens on glucose homeostasis.

The islet insulin content offers a guide to insulin biosynthesis and storage. Ovariectomy reduced islet insulin content whereas oestradiol and progesterone opposed this effect. This is consistent with previous evidence that oestrogens increase B-cell granulation [1-3]. The changes in islet insulin content may be correlated with changes in islet morphometry. Within the limits of the histological technique the present data show a considerable fall in B-cell number in ovarectomised mice. All three hormone treatments countered this effect, but the oestradiol-containing regimens were consistently more effective. The design of the present study does not allow us to distinguish whether sex hormones stimulate B-cell replacement, reduce B-cell loss, or promote islet neo-formation. However, studies in non-diabetic and experimentally diabetic rats have indicated that oestrogens possess the ability to increase B-cell division 
and islet neo-formation [1-3]. This would account for the beneficial effects of oestrogens in experimental diabetes.

In conclusion, we have shown that normal ovarian endocrine activity is important for the long-term functional integrity of the islet B-cells in the female. The present study substantiates evidence that endogenous sex hormone secretions modulate B-cell activity and glucose homeostasis during the reproductive cycle [6] and pregnancy $[5,33,34]$. The study also draws attention to the view that conditions of prolonged ovarian endocrine deficiency, such as the climacterium, may provide a diabetogenic stress which could be relieved by an appropriate hormone replacement regime.

Acknowledgement. The authors thank Ayerst Laboratories for their support.

\section{References}

1. Houssay BA (1951) Action of sex hormones on experimental diabetes. Br Med J II: 505-510

2. Rodriguez RR (1965) Influence of oestrogens and androgens on the production and prevention of diabetes. In: Leibel BS, Wrenshall GA (eds) On the nature and treatment of diabetes. Excerpta Medica, Amsterdam, p 288-307

3. Haist RE (1965) Effects of steroids on the pancreas. Methods Horm Res 4: 193-233

4. Goodman MN, Hazelwood RL (1974) Short-term effects of oestradiol benzoate in normal, hypophysectomized and alloxan-diabetic male rats. J Endocrinol 62: 439-449

5. Costrini NV, Kalkhoff RK (1971) Relative effects of pregnancy, estradiol, and progesterone on plasma insulin and pancreatic islet insulin secretion. J Clin Invest 50: 992-999

6. Bailey CJ, Matty AJ (1972) Glucose tolerance and plasma insulin of the rat in relation to the oestrous cycle and sex hormones. Horm Metab Res 4: 266-270

7. Sutter-Dub M-Th, Faure A, Aerts L, Van Assche FA (1978) Effect of progesterone and 17- $\beta$-oestradiol treatments on the pancreatic B cell in castrated female rats. J Physiol (Paris) 74: 725-730

8. Neill JD, Smith MS (1974) Pituitary-ovarian interrelationships in the rat. Curr Top Exp Endocrinol 2: 73-106

9. Bailey CJ, Atkins TW, Conner MJ, Manley CG, Matty AJ (1975) Diurnal variations of food consumption, plasma glucose and plasma insulin concentrations in lean and obese hyperglycaemic mice. Horm Res 6: 380-386

10. Gey GO, Gey MK (1936) The maintenance of human normal cells and tumor cells in continuous culture. I. Preliminary report: cultivation of mesoblastic tumors and normal tissue and notes on methods of cultivation. Am J Cancer 27: 45-76

11. Malaisse WJ, Malaisse-Lagae F, McCraw EF, Wright PH (1967) Insulin secretion in vitro by pancreatic tissue from normal, adrenalectomized and cortisol-treated rats. Proc Soc Exp Biol Med 124: 924-928

12. Hales CN, Randle PJ (1963) Immunoassay of insulin with insulin-antibody precipitate. Biochem J 88: 137-146

13. Midgley AR, Niswender GC, Regar RW (1969) Principles for the assessment of the reliability of radioimmunoassay methods (precision, accuracy, sensitivity, specificity). Acta Endocrinol (Kbh) 63 [Suppl 142]: 163-184

14. Gomori $G$ (1941) Observations with differential stains on human islets of Langerhans. Am J Pathol 17: 395-406
15. Wade GN (1975) Some effects of ovarian hormones on food intake and body weight in female rats. J Comp Physiol Psychol 88: 183-193

16. Blaustein JD, Gentry RT, Roy EJ, Wade GN (1976) Effects of ovariectomy and estradiol on body weight and food intake in gold thioglucose-treated mice. Physiol Behav 17: 1027-1030

17. Blaustein JD, Wade GN (1977) Ovarian hormones and meal patterns in rats: effects of progesterone and role of gastrointestinal transit. Physiol Behav 19: 23-27

18. Fishman J (1976) Appetite and sex hormones. In: Silverstone $\mathrm{T}$ (ed) Dahlem workshop on appetite and food intake. Dahlem Konferenzen, Berlin, p 207-218

19. Bailey $\mathrm{CJ}$ (1978) On the physiology and biochemistry of obesity. Sci Prog 65: 365-393

20. Kalkhoff RK (1975) Effects of oral contraceptive agents on carbohydrate metabolism. J Steroid Biochem 6: 949-956

21. Beck P (1969) Progestin enhancement of the plasma insulin response to glucose in rhesus monkeys. Diabetes 18: 146-152

22. Bhatia SK, Moore D, Kalkhoff RK (1972) Progesterone suppression of the plasma growth hormone response. J Clin Endocrinol Metab 35: 364-369

23. Matute ML, Kalkhoff RK (1973) Sex steroid influence on hepatic gluconeogenesis and glycogen formation. Endocrinology 92: 762-768

24. Hager D, Georg RH, Leitner JW, Beck P (1972) Insulin secretion and content in isolated rat pancreatic islets following treatment with gestational hormones. Endocrinology 91: 977-981

25. Lenzen S (1978) Effects of ovariectomy and treatment with progesterone or oestradiol-17 $\beta$ on the secretion of insulin by the perfused rat pancreas. J Endocrinol 78: 153-154

26. Bailey CJ, Matty AJ (1973) The short-term effects of oestradiol and progesterone on insulin secretion in vivo and in vitro in the female rat. International Congress Series 280. Excerpta Medica, Amsterdam, p 69-70

27. Howell SL, Tyhurst M, Green IC (1977) Direct effects of progesterone on rat islets of Langerhans in vivo and in tissue culture. Diabetologia 13: 579-583

28. Green IC, Howell SL, Seifi SEl, Perrin D (1978) Binding of ${ }^{3} \mathrm{H}$-progesterone by isolated rat islets of Langerhans. Diabetologia 15: 349-355

29. Ashby JP, Shirling D, Baird JD (1978) Effect of progesterone on insulin secretion in the rat. J Endocrinol 76: 479-486

30. Doe RP, Dickinson P, Zinnerman HH, Seal US (1969) Elevated non-protein-bound cortisol (NPC) in pregnancy, during estrogen administration and in carcinoma of the prostate. J Clin Endocrinol Metab 29: 757-766

31. Frantz AG, Rabkin MT (1965) Effects of estrogen and sex difference on secretion of human growth hormone. J Clin Endocrinol Metab 25: 1470-1480

32. Bailey CJ (in press) The hormonal regulation of insulin secretion. In: Ashwell M (ed) Clinical and scientific aspects of the regulation of metabolism. CRC Press, West Palm Beach, Fl

33. Green IC, Taylor KW (1972) Effects of pregnancy in the rat on the size and insulin secretory response of the islets of Langerhans. J Endocrinol 54: 317-325

34. Kalkhoff RK, Kim H-J (1978) Effects of pregnancy on insulin and glucagon secretion by perifused rat pancreatic islets. Endocrinology 102: 623-631

Received: January 28, 1980, and in rèvised form: June 30, 1980

Dr. C. J. Bailey

Department of Biological Sciences

University of Aston in Birmingham

Birmingham B4 7ET, England 